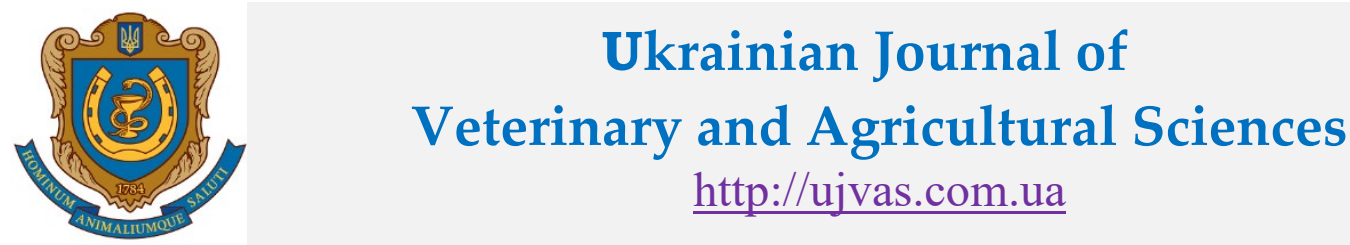

Stepan Gzhytskyi National University of Veterinary Medicine and Biotechnologies Lviv

\begin{tabular}{l|l|l} 
original article & UDC 619:616-091.8:59 $\quad$ doi: 10.32718/ujvas3-1.02
\end{tabular}

Volume 3

Number 1

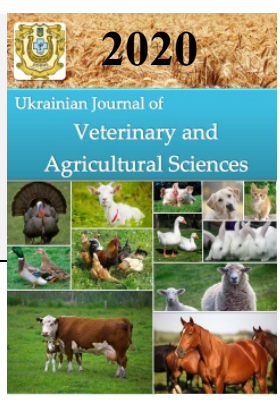

\title{
Pathoanatomical and pathogistological changes in organs and tissues of indian peafowl (Pavo cristatus) during histomonosis
}

\author{
O. Shchebentovska, M. Holubtsova
}

Stepan Gzhytskyi National University of Veterinary Medicine and Biotechnologies, Pekarska, Str., 50, Lviv, 79010, Ukraine

\begin{abstract}
Article info
Received 27.01.2020

Received in revised form

25.02 .2020

Accepted 26.02.2020

Correspondence author

Olga Shchebentovska

Tel.: +38-067-701-81-46

E-mail: Schebentovskaolga@gmail.com

2020 Shchebentovska O. et al. This

is an open-access article distributed

under the terms of the Creative

Commons Attribution License,

which permits unrestricted use,

distribution, and reproduction in any

medium, provided the original

author and source are credited.

Abstract

Histomonosis is a fairly common disease in poultry - turkeys, laying hens, guineafowls, geese, ducks. Spontaneous cases of histomonosis in Indian peafowls do not occur very often, thus they feature less frequently in the scientific literature. Among possible reasons for this to happen is that they are kept in zoos or at private farms, where their death is mainly attributed to complications caused by E. coli or Clostridium microorganisms. The article demonstrates pathoanatomical and pathohistological changes in the organs of Indian peafowls during spontaneous histomonosis characterized by liver and caecum lesions alongside developed multifocal necrotic hepatitis and diphtheria typhlitis. Clinical signs of the disease in Indian peafowls manifested with gradual feed refusal, the bird was becoming depressed and hiding its head under the wing. The first death of a female Indian peafowl was recorded 10-14 days after the onset of such clinical signs. During histological examination, massive necrotic lesions were detected in the liver and in places of intensive development of histomonas. Cell infiltration consisting of pseudo-eosinophils, lymphoid and histiocytic cells was formed around these lesions. The penetration of histomonas into the mucous membrane of the caecum caused proliferative processes by cellular elements, which was also accompanied by heterophilic-leukocyte infiltration and the formation of cell granulomas in places where histomonas were located.
\end{abstract}

\section{(cc) BY}

Key words: Indian peafowl, histomonosis, caecum, necrosis, liver, granulomas, cell infiltration.

Contents

1. Introduction

2. Materials and meth.........

Results and discussion ....... 10

Conclusions ................. 12

References ..................... 12

\section{Citation:}

Shchebentovska, O., \& Holubtsova, M. (2020). Pathoanatomical and pathogistological changes in organs and tissues of indian peafowl (Pavo cristatus) during histomonosis. Ukrainian Journal of Veterinary and Agricultural Sciences, 3(1), 9-12.

\section{Introduction}

Histomonosis (typhlohepatitis) is a disease caused by the protozoa; it causes damage to caecum and liver. The infective agent is Histomonas meleagridis - the simplest microorganism, which belongs to the genus Histomonas, Dientamoebidae family (McDougald, 2005; Callait-Cardinal et al., 2010; Van der Heijden et al., 2011; Hess et al., 2015).

It is difficult to overestimate the economic losses as a result of this disease, especially for industrial poultry breeding. Histomonosis remains a challenging disease not only for commercial poultry farms, but also for the ones dealing with exotic animals - especially among mini-zoos and homesteads where domestic and exotic birds are kept in small enclosures, irregardless of their age, breed and origin (Popp et al., 2011; McDougald et al., 2012; Oliveira et al., 2017; Costa et al., 2018). This disease has been studied substantially and mentioned as early as 1895 in turkeys, as well as in chickens. The research notes that chickens suffer its milder form, but can remain infection carriers for a long time. This fact specifically should be taken into account by farmers who run different poultry together. Lviv region's climate conditions and soil type (sod-podzolic soils and chernozem) contribute to the survival of heteroxysomes and earthworms that are intermediate hosts in the developmental cycle of Histomonas meleagridis.

According to a number of scientists who infected Indian peafowls (Pavo spp.) with histomonosis experimentally, it was possible to record typical pathomorphological changes in the liver and caecum. In a natural environment, however, the death of Indian peafowls from histomonosis was rarely recorded. Retrospective studies by US veterinary-diagnostic laboratories have revealed only 5 cases of Indian peafowls featuring characteristics of histomonosis and pathohistological changes. The affects included the development of bilateral fibrinous-necrotic typhlitis and necrotic hepatitis (trophozoites detected), which identified as Histomonas 
meleagridis due to their morphological features and as a result of PCR.

Alimentary infection is most usual for poultry while intermediate hosts of histomonas - helminths of Heterakis gallinarum, their larvae and eggs - play a significant role in its development, as noted above. Ectoparasites - flies, fleas, ticks (most often cause diseases in young birds) can also act as carriers of histomonas.

Disease starts to develop when histomonas penetrate the wall of the caecum. The sites of primary localization are places where $\mathrm{pH}$ levels are most favorable for the reproduction and development of histomonas. They enter blood circulatory system through the wall of the caecum, and hematogenously proceed to the liver via a portal vain. Clinical symptoms of histomonosis manifest within 7-12 days (usually after 11 days) after infection. The litter turns yellow, the bird becomes drowsy, its wings are down, it starts wobbling. Birds with their head down or head hidden under their wings, their eyes closed, can be often spotted within the flock. Bird's head may be turning bluish, but this is not always the case and it is not one of the pathognomonic indicators during histomonosis (Hauck \& Hafez, 2013; Dolka et al., 2015; Michelazzo et al., 2017).

\section{Materials and methods}

Samples for pathohistological analysis were taken from three spontaneously ill 8 months old Pavo cristatus females, who died at 10-14 days after the first clinical signs of the disease were spotted. Indian peafowls were kept at a rural household in Lviv region. Special feed for pheasants and guineafowls was used to feed these birds. Pathoanatomical incision was performed at the prosectorate of the Department of Normal and Pathological Morphology and Forensic

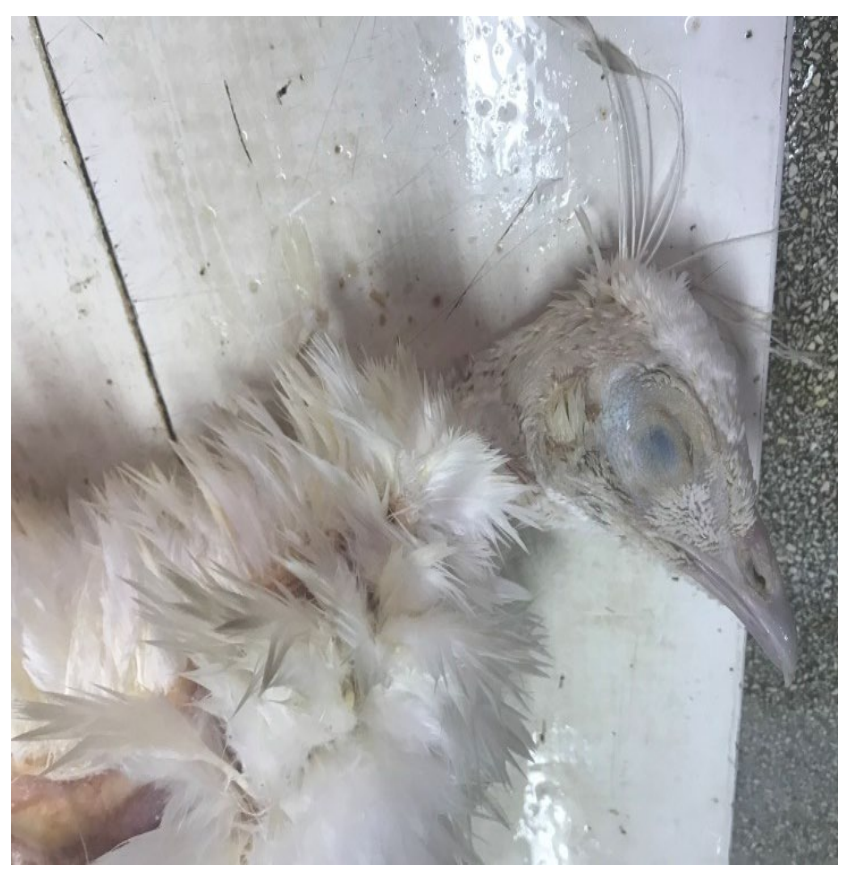

Fig. 1. Pavo cristatus female that died from histomonosis
Veterinary of Stepan Gzhytskyi National University of Veterinary Medicine and Biotechnologies Lviv. Fragments of liver and ceacum were collected for histological examination and fixed in $10 \%$ aqueous formalin neutral solution. Fragments of selected tissues were fixed in formalin solution and dehydrated in an ascending row of alcohols, followed by paraffin blocking using the standard method. Histological sections $7 \mu \mathrm{m}$ thick were cut from paraffin blocks on the MC-2 dome microtome (Merkulov, 1953; Kiceli, 1962; Merkulov, 1963; Horalckyi et al., 2005).

Paraffin sections were fixed in a formalin solution and stained with Mayer hematoxylin and eosin for optical microscopy. Light microscopy and photomicrography of histological slides were performed using a Leica DM-2500 microscope and a Leica DFC 450C camera.

\section{Results and discussion}

During pathological anatomical dissection of Pavo cristatus females (Fig. 1), major changes were found in the caecum and liver. The caecum was enlarged, had thickened walls, diffuse hemorrhages and nodules, sizes ranging from a millet grain to small pea (Fig. 2). The contents of the caecum looked gray-green in color with lots of mucus and fibrinous-necrotic masses that filled the entire intestines (Fig. 3). The liver was enlarged, full-blooded, dark brown in color and featuring diffuse necrotic areas of various size that were yellowish-white in color, with a clasped center surrounded by a light, round rim (Fig. 4). Necrotic foci were sometimes fused and formed nodular outgrowths - matters that protruded above the surface of the liver. The gallbladder was enlarged, overflowing with thick, green bile. No visible macroscopic changes to other parenchymal organs (kidneys, spleen, lungs) were detected.

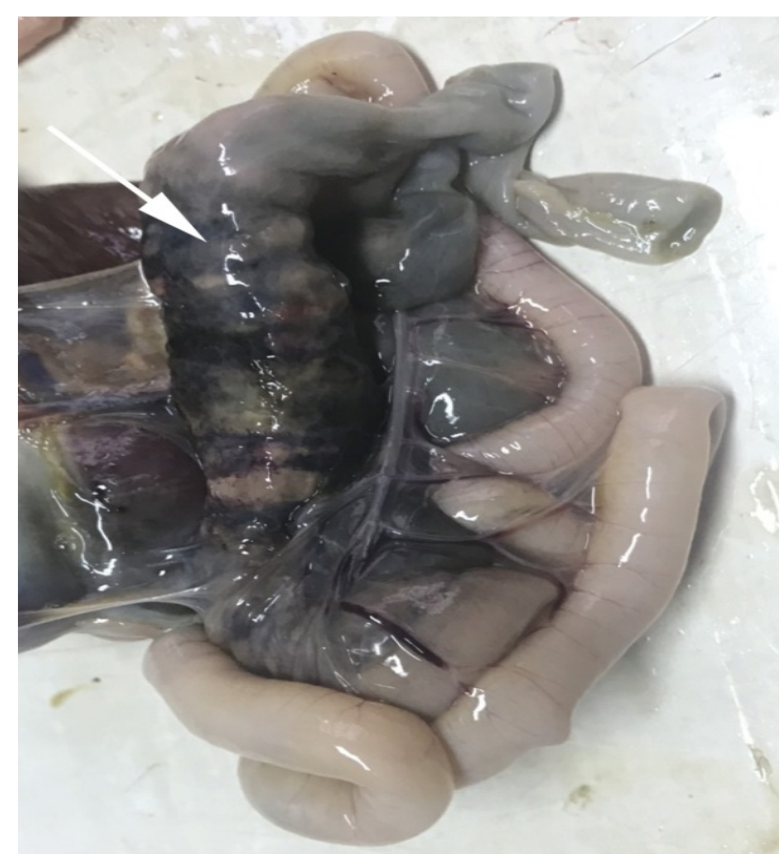

Fig. 2. Forming of white nodules in the wall of the caecum (follow the arrow) 


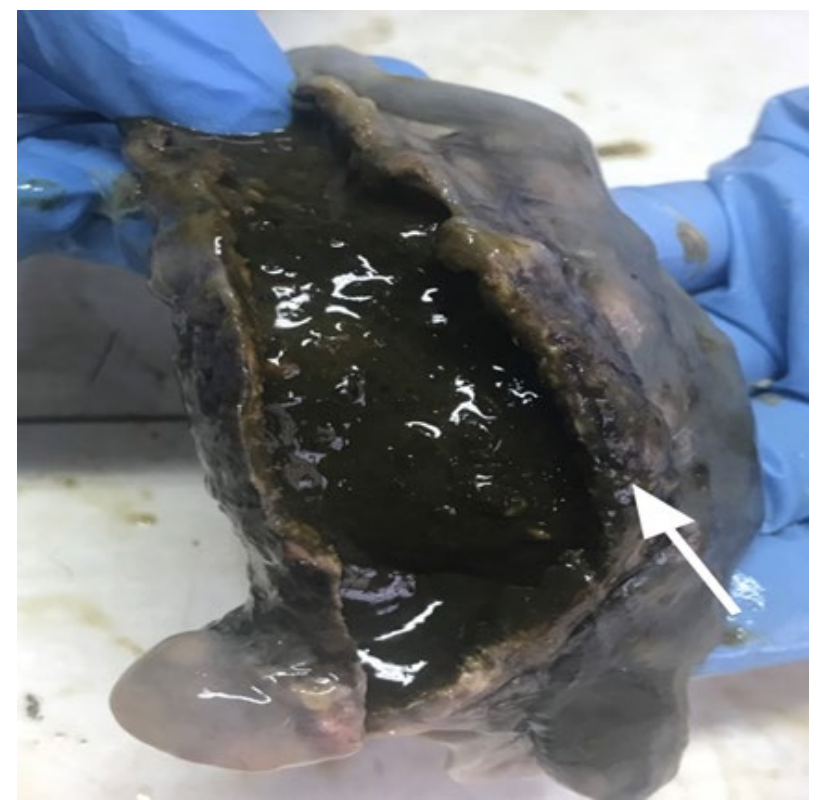

Fig. 3. Thickening of the wall of the caecum, necrosis of the mucous membrane with diphtheritic layers

Necrosis of the mucous membrane and crypts was histologically identified in the caecum of Pavo cristatus females. It formed a structureless granular mass, in which histomonas were located. The submucosa was infiltrated with leukocytes. The border between the mucous and submucosal bases was hardly visible. In addition, pathohistological changes in the caecum's epithelium were evident in the intense cellular response and the formation of different-sized granulomas (Figs. 5, 6). The penetration of histomonas into the mucous membrane of the caecum caused proliferative processes on the part of the cellular elements, which was accompanied by heterophilic-leukocyte infiltration and the formation of cellular granuloma in places where histomonas were located. Morphologically, histomonas at various stages

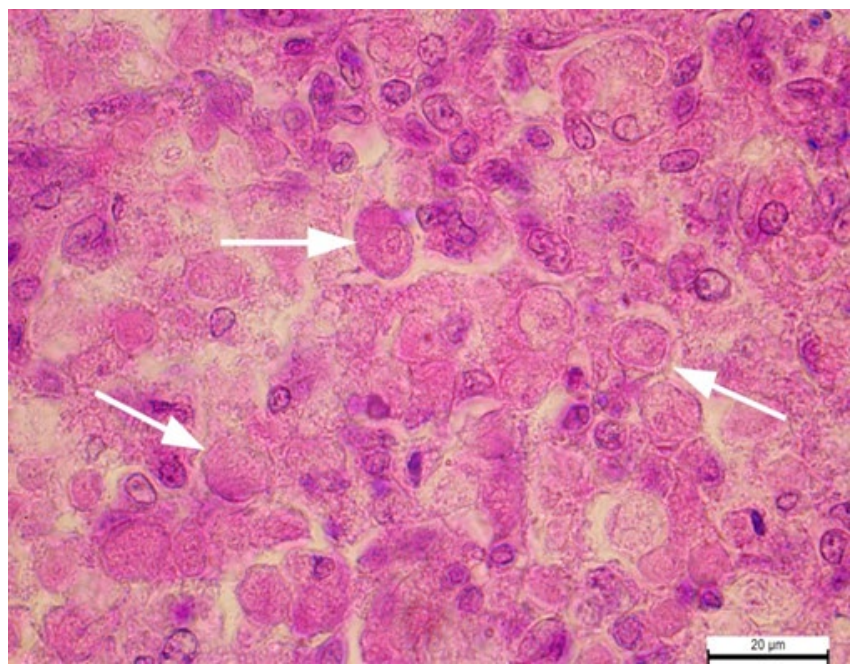

Fig. 5. Caecum. Histomonas at different development stages (follow the arrows). Hematoxylin and eosin. $x 400$

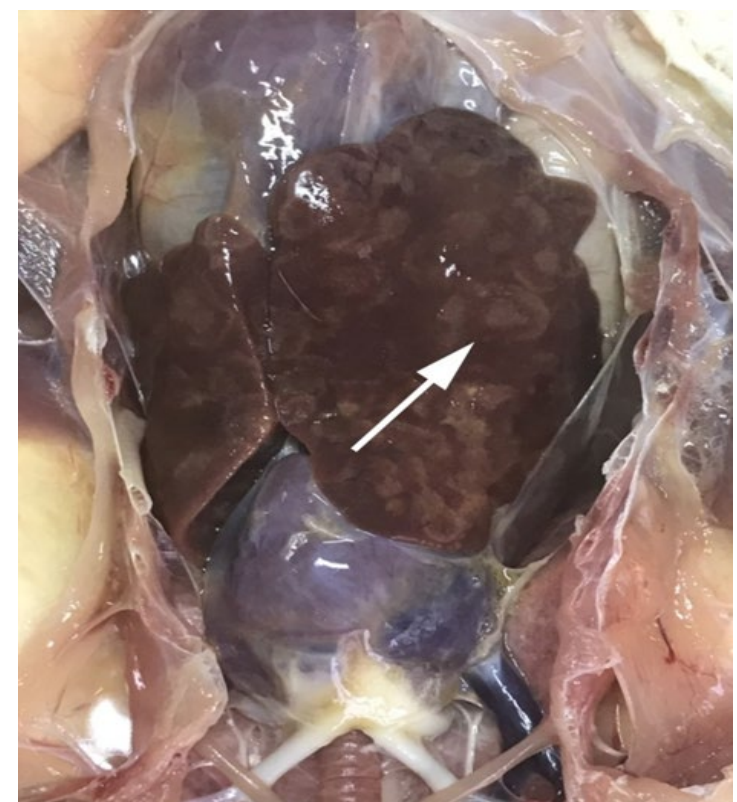

Fig. 4. Liver. Necrotic foci surrounded by a round rim (follow the arrow)

of their development look like light, slightly pinkish oval bodies with their own shell, while lymphocytes and macrophages concentrate around them.

Histological examination of the liver of Pavo cristatus females showed necrotic foci in areas of intensive development of histomonas. The degree of damage to hepatocytes was different: the cells lost shape, the cytoplasm became see-through, the nuclei could hardly be noticed, and underwent karyolysis. Intraparticular hemocapillaries expanded. Formations of cell infiltrations consisting of pseudoeosinophils, lymphoid and histiocytic cells (Figs. 7, 8) were typical. Necrotic masses and cell infiltrates also revealed histomonas at various stages of development.

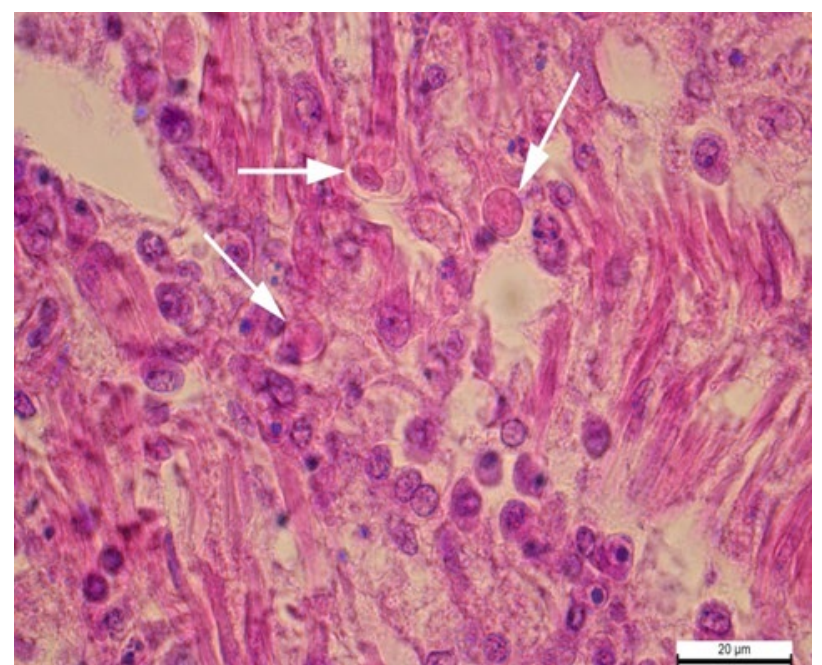

Fig. 6. Caecum. Cellular response around histomonas. Hematoxylin and eosin. $x 400$ 


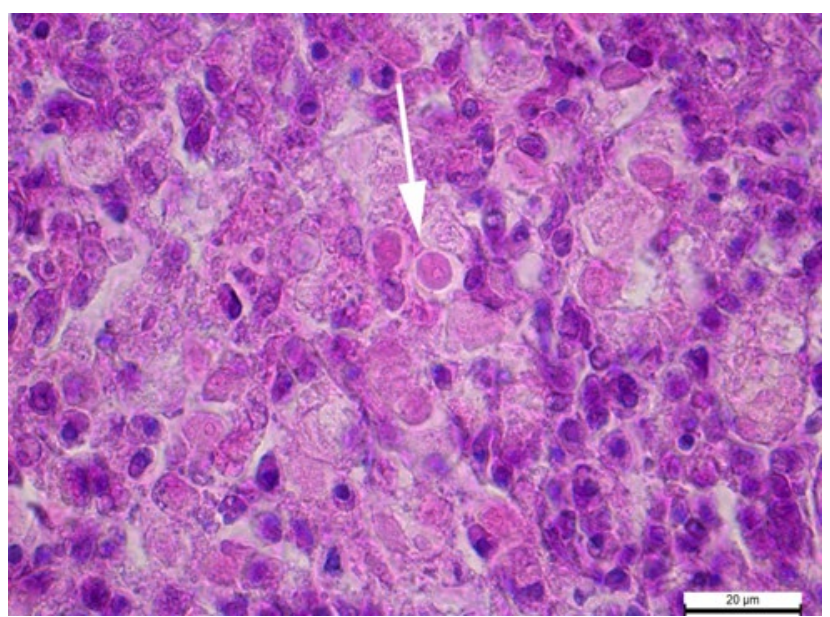

Fig. 7. Liver. Histomonas at different development stages (follow the arrow). Hematoxylin and eosin. $x 400$

\section{Conclusions}

1. Pathologic anatomical changes in spontaneous histomonosis of Pavo cristatus females were characterized by multifocal necrotic hepatitis and diphtheritic typhlitis.

2. Pathohistological changes were characterized by necrosis, intensive cellular reaction by pseudo-eosinophils, lymphoid and histiocytic cells and formation of different size granulomas.

3. The intensity of the invasion and the rate at which the pathogen spreads from the primary site - the caecum - to the liver, probably depends on the reactivity of the host. The course of the disease often depends on the species composition of the caecum microflora. The development of the disease is especially accelerated by the presence of bacteria of the genus E. coli and Clostridium perfringen that create favorable conditions for solid metabolic integrity of histomonas, and can also complicate the course of histomonosis with the by-products of their vital functions.

\section{References}

Callait-Cardinal, M. P., Gilot-Fromont, E., Chossat, L., Onthier, A. (2010). Flock management and histomoniasis in free-range turkeys in France: description and search for potential risk factors. Epidemiol Infect., 138(3), 353-363. doi: $10.1017 / \mathrm{S} 0950268809990562$.

Clarke, L. L., Beckstead, R. B., Hayes, J. R., \& Rissi, D. R. (2017). Pathologic and molecular characterization of histomoniasis in peafowl (Pavo cristatus). Journal of Veterinary Diagnostic Investigation, 29(2), 237-241 doi: 10.1177/1040638716687002.

Costa, R. A., Pereira, A. P. M., Silveira, C. S., \& Anjos, B. L. (2018). Infecção natural por Histomonas meleagridis em pavões-indianos (Pavo cristatus). Acta Scientiae Veterinariae, 46(1), 333. doi: 10.22456/1679-9216.88166.

Dolka, B., Žbikowski, A., Dolka, I., \& Szeleszczuk, P. (2015). Histomonosis - an existing problem in chicken flocks in Poland. Vet. Res. Commun., 39(3), 189-195. doi: 10.1007/s11259-015-9637-2.

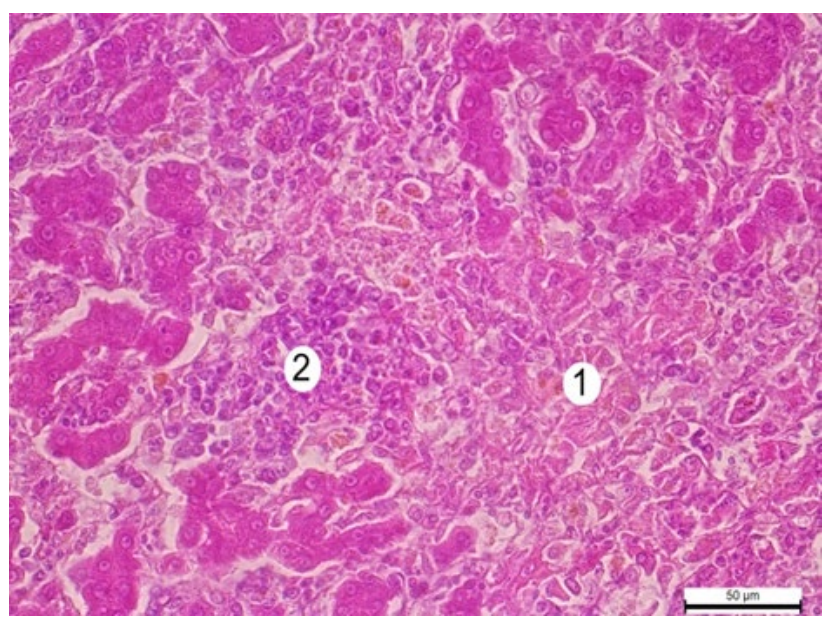

Fig. 8. Liver. Hepatocyte necrosis (1), cellular infiltration

(2). Hematoxylin and eosin. $x 200$

Hauck, R., \& Hafez, M. H. (2013). Experimental infections with the protozoan parasite Histomonas meleagridis: a review. Parasitology Research, 112(1), 19-34. doi: 10.1007/s00436-012$3190-5$

Hess, M., Liebhart, D., Bilic, I., \& Ganas, P. (2015). Histomonas meleagridis - New insights into an old pathogen. Veterinary Parasitolog, 208(1-2), 67-76. doi: 10.1016/j.vetpar.2014.12.018.

Horalckyi, L. P., Khomych, V. T., Kononckyi, O. I. (2005). Ocnovy hictolohichnoi tekhniky i morfofunktsionalni metody doclidzhennia u normi ta pry patolohii. Zhytomyr (in Ukrainian).

Kiceli, D. (1962). Prakticheckaja mikpotehnika i gictohimija. Budapesht (in Russian).

McDougald, L. R. (2005). Blackhead disease (histomoniasis) in poultry: a critical review. Avian Dis., 49(4), 462-476. doi: 10.1637/7420-081005R.1.

McDougald, L. R., Abraham, M., \& Beckstead, R. B. (2012). An outbreak of blackhead disease (Histomonas meleagridis) in farmreared bobwhite quail (Colinus virginianus). Avian Dis., 56(4), 754-756. doi: 10.1637/10140-032212-Case.1.

Merkulov, G. A. (1953). Mikpockopicheckaja tehnika. Mockva: Izdatel'ctvo inoctrannoj literatury (in Russian).

Merkulov, G. A. (1969). Kurc patologicheckoj tehniki. L. (in Russian).

Michelazzo, M. M. Z., Sasse, J. P., de Souza, M., Marutani, V. H. B., Sampaio Baptista, A. A., Garcia, J. L., Alfieri, A. A., \& Headley, S. A. (2017). Systemic histomoniasis in a Leucistic Indian Peafowl (Pavo cristatus) from Southern Brazil. Avian diseases, 61(3), 325-329. doi: 10.1637/11583-010617-RegR.

Oliveira, L. G. S., Boabaid, F. M., Lorenzett, M. P., Rolim, V., Santos, H.F., Driemeier D., \& Cruz, C. E. F. (2017). Outbreaks of mycoplasmosis and histomoniasis in a southern Brazilian flock of ornamental birds. Acta Scientiae Veterinariae, 45(1), 200. doi: 10.22456/1679-9216.85684.

Popp, C., Hauck, R., Balczulat, S., \& Hafez, H. M. (2011). Recurring histomonosis on an organic farm. Avian Diseases, 55(2), 328-330. doi: 10.1637/9596-110810-Case.1.

Van der Heijden, H. M. J. F., Landman, W. J. M. (2011). High seroprevalence of Histomonas meleagridis in Dutch layer chickens. Avian Dis, 55(2), 324-327. doi: 10.1637/9609120610-ResNote.1. 